\title{
Proceeding
}

\section{Pilot study on sprint training methods in different types of athletes}

\author{
FEDERICA PISAPIA ${ }^{1} \triangle$, ARIO FEDERICI ${ }^{2}$, MANUELA VALENTINI², TIZIANA D'ISANTO1 \\ 1 University of Salerno, Italy \\ 2University of Carlo Bo Urbino, Italy
}

\begin{abstract}
From the recognition of the scientific literature it emerges that the International Paralympic Committee and the Italian Paralympic Committee, together with the Special Olympics, present a segregative imprint in sports activities, as the current Regulations allow the restricted participation to specific types of disabilities, excluding the inclusion of others, so the difficulty lies in finding a different method that is suitable for all the different types of athletes. Taking up the two approaches (cognitive and ecological), mentioned in the previous study, it is preferable to limit the method of prescriptive teaching for athletes with disabilities on $100,200,400 \mathrm{~m}$, because they must adapt to a diversity compared to non-disabled people. For this reason, the adaptation is personal and then it occurs according to the heuristic learning method. Therefore, the integration of the above mentioned approaches is proposed, giving shape to a model characterized by a specific training of organic and muscular adaptations, also in qualitative terms, with the integration of heuristic learning and types of periodization and training methods with differences in the competition rules. The aim of this study is to hypothesize, through the theoretical method, a model that is able to enhance all types of athletes, according to their specific characteristics. Key words: Disabled athlete; Cognitive approach; Ecological-Dynamic approach; Prescriptive teaching; Heuristic learning; IPC.
\end{abstract}

\section{Cite this article as:}

Pisapia, F., Federici, A., Valentini, M., \& D'Isanto, T. (2019). Pilot study on sprint training methods in different types of athletes. Journal of Human Sport and Exercise, 14(2proc), S189-S197. doi:https://doi.org/10.14198/jhse.2019.14.Proc2.05

\section{Corresponding author. University of Salerno, Italy.}

E-mail: federicapisapia95@gmail.com

Supplementary Issue: Winter Conferences of Sports Science. Costa Blanca Sports Science Events, 25-26 January 2019. Alicante, Spain.

JOURNAL OF HUMAN SPORT \& EXERCISE ISSN 1988-5202

(c) Faculty of Education. University of Alicante.

doi:10.14198/jhse.2019.14.Proc2.05 


\section{INTRODUCTION}

The transition from total indifference, towards people with disabilities, to the integration process before and inclusion after, was slow and gradual. Only at the turn of the nineteenth and twentieth centuries began to expand throughout Europe the educational interest for all forms of disability, a process that led these subjects to enter the common school system, in fact we speak of integration. It guarantees the respect of personal educational needs within everyone's school, providing for individualized planning, openness to flexible and functional organizational methods and teachers' figures for support (Fiorin, 2007). However, in the integrative model the idea still prevails that the subject is "special" and must be supported by mainly technical interventions. For this reason, the integrative model becomes a paradigm that the scientific and professional world summarizes in the expression of inclusion. According to this model, the person who bears the diversity enters the community fully, like everyone else. Thus understood, inclusion can take place not only between multiple categories of person, but also in school or in different environments (family, work, sport, etc.) (D'Isanto, Di Tore, 2016, D'Isanto, 2016). In recent years there has been an increasing focus on the recognition of universal rights and the realization of the aspirations and potential of each person, also a bearer of diversity and, in particular, of disability (Pavone, 2014). In fact, anyone who decides to take care of teaching/training of physical and sporting activities must be able to make appropriate methodologicaleducational decisions (Cassese, F.P., Raiola, 2017). In particular, we distinguish two main approaches to motor control and learning: the cognitive and the ecological-dynamic one, already mentioned in the preliminary study (Pisapia, D'Isanto, 2018), which present differences both on the theoretical and on the methodological-didactic levels, which consequently lead to substantially different conclusions. The first one implies a prescriptive teaching, the second one a heuristic learning. It is obvious to say that the choice of the two approaches is carried out taking into consideration what are the physical characteristics of each, the motor task to be taught and the context in which the learning takes place. Wanting to analyse each of the two approaches in more detail, the cognitive one lays the foundations on the behavioural and cognitivist theories that have developed (motor control theories), which affirm that in the brain are stored motor programs deputies to coordinate the execution of movements and they include:

- $\quad$ Closed loop motor control (Adams 1968): if the movements are slow enough, the information coming from the sense organs can be used to correct the movement during its execution;

- Open loop motor control (Schmidt 1985, Keele et al., 1986): if the movement time is shorter than the conduction of the nerve impulses, because the movement must be programmed a priori and is not liable to correction during its execution;

- Generalized motor program (Schimdt, Wrisberg 2004): It believes that a generalized program contains motor commands that define the common structure to an entire movement class, while the surface characteristics of each individual movement are defined from time to time.

From the integration of the cognitive theories of motor control, derives the cognitive theory of motor learning (Schmidt, Wrisberg, 2008), according to which "learning" means developing specific cognitive structures that allow information processing. Motor development is linked to cognitive development in a bidirectional way, because the development of motor skills influences the possibility of a rapid growth of cognitive experiences and, at the same time, the evolution of these latter leads to new motor experiences (Magill, 2011; Smidt, Lee, 1999; Singer, 1980). We can distinguish different strategies/techniques for structuring the exercise, such as: partial exercise; randomized exercise; varied exercise; feedback delivery techniques; mental repetition. In the cognitive approach prevails the concept of a prescriptive method, according to which the coach must apply the means and methods of teaching facilitation suitable for each subject, for a specific task and in a particular context without altering the structure of the motor program. 
As regards, instead, the ecological-dynamic approach, it is based on the complex relationship between the individual-task-environment. Differently from the cognitive approach, the ecological-dynamic one enhances the variability of the practice and the active role of the athlete, the guided discovery, the self-evaluation of learning and the resolution of problems (Raiola, 2014, Raiola 2012). At the basis of this approach there is the theory of degrees of freedom, or even defined Bernstein's problem, by Nikolai Alexsandrovich Bernstein (Bernstein, 1967), which is divided into 3 stages:

- $\quad$ Reduction of degrees of freedom: it represents the initial phase of motor learning. Since the pupil at the start is probably unable to adequately control the enormous amount of freedom present in the neuromuscular system and in the environment, it is useful to reduce them to facilitate the solution of the motor task using the available resources and the learning potential that already has. Among the recommended methods to reduce degrees of freedom there are the locking of the joints and the symmetrisation of the movements;

- Exploration of degrees of freedom: it represents the second phase of learning and it is the reverse process to the previous one. The pupil is able to perform the movement in its initial form, simplified by the reduction of the number of joints involved or by the symmetry of movement of the limbs, additional degrees of freedom can be recruited by progressively coordinating the movement of an ever increasing number of joints;

- Capitalization of degrees of freedom: it represents the third phase. "Capitalizing" means optimizing and exploiting external forces (gravity and inertia) to the body and internal forces (muscle elasticity), to make the movement cheaper. This last phase involves the pupil in both ecological and dynamic dimensions, with considerable mental involvement in symbiosis with the context.

Therefore, according to the dynamic approach, motor learning consists in controlling and gradually exploiting the degrees of freedom and being able to find the best motor solution for a given task. For this reason, we talk about heuristic learning, according to which the coach assists the athlete in the autonomous research for motor solutions. It is interesting how the coaches focus particularly on this type of approach, which sees the environment as the centre of the learning process and which aims to solve the different problems. In this type of approach, the main strategies/techniques to suggest to athletes could be those adapted from psychology such as: circle time; cooperative learning; role playing; peer education; focus group; brainstorming, etc. These techniques involve the felt and conscious participation of the athlete, because they contextualize the learning situations in real environments similar to those that the pupil has experienced in the past, those who currently lives and those who will live in the future (Di Tore et al., 2016, Di Tore et al., 2018). The techniques mentioned above are characterized by:

- $\quad$ "Experienced" participation;

- Constant control and self-assessment;

- Training in situation;

- Group training.

\section{METHODS}

Not having a group available on which to perform an experimental research, the method adopted in this study is of a theoretical type, more specifically of a logical-rational-deductive type. Differently from the preliminary study, which had as its aim the theoretical elaboration of a project, the pilot study foresees an initial application, on a small scale, of the project itself, in order to verify its adequacy, feasibility or obtain information that allows to determine a sample, in this case, of theoretical models. With this work we want to 
analyse the aspects of the cognitive approach and, more specifically, of the ecological-dynamic one through an integrated method: on one side, through a theoretical approach, they are elaborated all the theoretical paradigms on the teaching / learning methods of motor and sport activities; on the other, through a deductive approach, a new model is hypothesized characterized by a specific training of organic-muscular adaptations, also qualitative, with the integration of heuristic learning and types of periodization and training methods with differences in competition rules.

\section{RESULTS}

Below it is presented the general structure of a training adapted model, which sees the inclusion of all athletes (disabled and non-disabled), which are required to compete on a racing wheelchair. The choice of the wheelchair frame (racing wheelchair for everyone, footbike for the arms amputations) occurs after a series of accurate anthropometric measurements and technical observations. The adaptation provides different methodologies of participation compared to current ones and some regulatory changes, aimed at ensuring the inclusion of all athletes without going to negatively affect the performance of the latter. Of fundamental importance is the periodization of training (Bompa T., Buzzichelli C. 2016), where "periodization" means a division of the training process into periods. It is a process that incorporates both the planning (structuring of the training process to achieve a final performance goal) and the programming (more detailed drafting of the training program), in short words represents the structure of the temporal plan and its content (means and methods of training) that varies over time.

The planning of the proposed training includes a series of main objectives to be achieved at the end of the year, such as:

- Promote the construction of an inclusive society to combat forms of discrimination thanks to the educational values of sport;

- Encourage participation in motor and sports activities to people with disabilities or not, through adapted training methods that take into consideration the individual circumstances of the athlete;

- Development of motor experiences;

- General physical preparation;

- Development of resistance, speed-force, rapidity, coordination;

- Improvement of the technique;

- Creation of the athlete's competitive bases;

- Development of autonomy and knowledge.

The training includes an annual periodization divided into 4 periods:

- IPERIOD: INCLUSION $\rightarrow$ the aim of this period is to promote the inclusion process. All athletes, disabled or not, are subjected to exercises of an inclusive nature in which they must experience the disabilities of others. For these types of exercises, is preferred an ecological-dynamic approach, in which the athletes are free to experiment the wheelchair guide without the directives, by the coach, on the right modalities. Taking into consideration some of the techniques / strategies that this approach proposes, the methodologies that we want to adopt are: role playing and cooperative learning. For what concern the role playing, it is a simulation of the behaviours and attitudes generally adopted in real life. Athletes must take the roles assigned by the coach and behave as they think they would actually behave in the given situation. This technique aims to teach the ability to play a role and to understand in depth what the role requires 
(Tessaro, F., 2002). So, we ask the athletes to put themselves in the other's shoes to understand the difficulties of each one (Ex. We ask the athletes to run blindfolded to put themselves in the shoes of a blind person, or they use earplugs to put themselves in the shoes of a deaf, and so on). Instead, for what concern the cooperative learning, it is a learning method in which athletes work together in small groups to achieve common goals, trying to mutually improve their learning (Comoglio, M., Cardoso, M., A., 1996). Therefore, the athlete with a specific disability (blind, deaf) helps his teammates in the execution of the exercises giving indications on the correct execution. Only later, the coach intervenes by correcting any errors with indications on the correct techniques in the execution of the exercise, according to the prescriptive method;

- II PERIOD: GENERAL $\rightarrow$ the aim is to increase resistance, strength and rapidity on the wheelchair. The work, therefore, focuses on general physical preparation and training rhythms will be bland. The athletes will be gradually used to increasing amounts and intensity of work, both in the gym, to develop/tone the upper or lower limbs (depending on the type of disability), and on the track so as to ensure a basic physical preparation equal for all. For the improvement of resistance, is adopted a methodology that includes exercises interrupted by equal pauses between them. They are provided continuous and repeated runs over long distances and freebody physical training exercises (Rago, Pizzuto, Raiola, 2017). For the increase of force-speed, the method of repeated efforts is useful for the muscular construction of the subject. Moreover, loads below the maximum are useful for learning the execution technique. They are expected exercises with overloads such as barbell, dumbbells, medicine balls, wheelchair rides with towing. For the development of rapidity, they are expected rapid running exercises in wheelchairs, fast arm swings, rapidity along a line (straight or lateral), with a circle (limited movements inside and outside of it, useful for manoeuvres in curve), acceleration and deceleration exercises in a straight line at a moderate and sustained speed, acceleration with short and frequent thrusts (Raiola, Di Tore, 2012, Raiola, 2012);

- $\quad$ III PERIOD: SPECIAL $\rightarrow$ the training is connected to the specificity of the test, even if it is not yet completely specific. In particular, it is based on a special speed training, in which higher speeds are sought. They are expected reactive, explosive, elastic and power exercises, acceleration exercises with short and frequent thrusts, rapid running exercises, tests at maximum speed (Raiola, Rago, 2014, Raiola, 2013). To avoid creating standardization situations, it is used the varied exercise, which consists in making more movements belonging to the same class, that is, more executive variations of the same generalized motor program. Therefore, the means of training must be varied in such a way as to allow the subject to always engage the nervous and muscular system as much as possible without these determining "standard mechanical speeds". The succession of the coaching means during the preparation foresees the following progression: uphill race, stroke with the towing, stroke with the ballasted jacket, running flat in conditions similar to the race, downhill race, towed run, run behind the open-air screen. In this way, the ecological approach is exploited by not taking into consideration the aspects of motor coordination within the individual but, applying constraints to the environment, we take into consideration the complex interaction between the individual and the environment and the circular relationship between perception and action. They are used only those exercises that the athlete is able to perform perfectly after a training to reduce the degrees of freedom. These stages lead to the improvement of the technique and its economy (Altavilla, D'Isanto, Di Tore, Raiola, 2018); 
- IV PERIOD: SPECIFIC $\rightarrow$ the training is directly connected to the test. The limit between Special and Specific is very small, because it is only a question of changing the percentage of a type of training. It consists in the creation of competitive bases and particular attention is paid to the wheelchair pushing technique (Altavilla et al., 2018, Altavilla et al, 2015, Altavilla, 2014).

\section{DISCUSSION}

Numerous studies have shown performance optimization through the cognitive process (Raiola, 2017, Raiola, Di Tore, 2017). However, from the analysis carried out on the theories of the cognitive and ecologicaldynamic approach, it can be deduced that the assumption of dynamic systems leads to equal educational implications, sometimes superior, to those of the cognitive approach. Even if this latter is applied exclusively in high-performance sports, it is good to introduce in the teaching activity the perception/action present within the ecological approach.

\section{CONCLUSIONS}

The following research aims to promote the inclusive paradigm to ensure equal participation in the race of all athletes (disabled and not disabled). For this reason, a training model was conceived to enhance all athletes according to their specific characteristics, adapting the competition rules to all categories of athletes (D'Isanto et al., 2019, D'Isanto, 2019). In particular, they are used a series of specific exercises and training programs to adopt different methods and/or strategies, based on the type of disability, to achieve common objectives (D'Elia, 2019).

\section{REFERENCES}

Adams, J.A. (1968). Response feedback and learning. "Psychological Bulletin", 70, 486-504. teaching relevance and availability of Anochin's theoretical model Sport Science Vol. 4, (2). https://doi.org/10.1037/h0026741

Altavilla, G. (2014) Effects of the practice of muscle stretching [Učinci vježbanja stretchinga muskulature] Sport Science, 7 (1), 66-67.

Altavilla, G., D'Elia, F., Raiola, G. (2018) A brief review of the effects of physical activity in subjects with cardiovascular disease: An interpretative key, Sport Mont, 16 (3), 103-106. https://doi.org/10.26773/smi.181018

Altavilla, G., Di Tore, P.A. (2016) Physical education during the first school cycle: A brief social psychopedagogical summary. Journal of Physical Education and Sport, 16 (2), 340-344.

Altavilla, G., Di Tore, P.A., Riela, L., D'Isanto, T. (2017) Anthropometric, physiological and performance aspects that differentiate male athletes from females and practical consequences, Journal of Physical Education and Sport, 17, 2183-2187.

Altavilla, G., D'Isanto, T., Di Tore, A.P., Raiola, G. (2018) Free throw and outcomes: Pilot study on intensive training versus extensive one, Journal of Human Sport and Exercise, 13 (3), 494-503. https://doi.org/10.14198//hse.2018.133.02

Altavilla, G., D'isanto, T., Di Tore, P.A. Anthropometrics characteristics and jumping ability in basketball (2018). Journal of Human Sport and Exercise, 13(Proc2): S385-S392. https://doi.org/10.14198/ihse.2018.13.Proc2.22

Altavilla, G., Furino, F., Marika, D.P., Raiola, G. (2015) Physical skills, sport learning and socio-affective education [Fizičke vještine, sportsko učenje I društveno-afektivno obrazovanje], Sport Science, 8, pp. 44-46. 
Altavilla, G., Gaetano, R. (2018) Physiological effects of warm-up and problems related to team sports, Sport Science, 11, 83-88.

Altavilla, G., Mazzeo, F., D'Elia, F., Raiola, G. (2018) Physical commitment and specific work for each role in an elite soccer team, Journal of Physical Education and Sport, 18 (2), 570-574.

Bernstein, N.A. (1967) The co-ordination and regulation of movements. Oxford: Pergamon Press.

Bompa T., Buzzichelli C. (2016) Periodizzazione dell'Allenamento Sportivo - $3^{\circ}$ Edizione, Calzetti \& Mariucci, 16, p. 120.

Cassese, F.P., Raiola, G. (2017) The importance of sport in disability management [Važnost sporta u upravljanju kod invaliditeta] Sport Science, 10, 7-11.

Cirillo, G., Nughes, E., Acanfora, A., Altavilla, G., D'lsanto, T. (2016) Physical and sport education testing by quantitative and qualitative tools in assessment in senior school: A proposal. Sport Science, 9, 97-101.

Comoglio, M., Cardoso, M., A., (1996) Insegnare e apprendere in gruppo. II Cooperative Learning. LAS Roma, 96.

D'Isanto, T. (2016) Pedagogical value of the body and physical activity in childhood [Pedagoška vrijednost tijela i tjelesne aktivnosti u djetinjstvu], Sport Science, 9, 13-18.

D'Isanto, T., D'Elia, F., Raiola, G., \& Altavilla, G. (2019). Assessment of sport performance: theoretical aspects and practical indications. Sport Mont, 17(1), 79-82. https://doi.org/10.26773/smj.190214

D'Isanto, T., Di Tore, P.A. (2016) Physical activity and social inclusion at school: A paradigm change. Journal of Physical Education and Sport, 16, pp. 1099-1102.

D'Isanto, T. (2019) Physical and sport education between Italian academic system and European Research Council structure panel. Journal of Human Sport and Exercise, 14, S66-S76. https://doi.org/10.14198/ihse.2019.14.Proc1.08

D'Isanto, T., Di Tore, P. \& Altavilla, G. (2018). Correlation of the anthropometric characteristics and the ability to jump in volleyball. Journal of Human Sport and Exercise, 13(2proc), S393-S400. https://doi.org/10.14198/ihse.2018.13.Proc2.23

D‘Elia, F. (2019). The training of physical education teacher in primary school. Journal of Human Sport and Exercise, 14(1proc), S100-S104. https://doi.org/10.14198/ihse.2019.14.Proc1.12

Di Tore, A.P., Raiola, G., D'Isanto, T. (2018) Situation awareness in sports science: Beyond the cognitive paradigm [Situacijska svijest u sportskoj nauci: Van kognitivne paradigme], Sport Science, 11 (1), 44-48.

Di Tore, P.A., Raiola, G. (2012) Case study on physical education and sport in Naples, Italy, Mediterranean Journal of Social Sciences, 3 (11), 471-476.

Di Tore, P.A., Raiola, G. (2012) Exergame-design and motor activities teaching: An overview of scientific paradigms on motor control, Mediterranean Journal of Social Sciences, 3 (11), 119-122.

Di Tore, P.A., Raiola, G. (2012) Exergames in motor skill learning, Journal of Physical Education and Sport, 12 (3), 358-361.

Di Tore, P.A., Raiola, G., Altavilla, G., Barba, S., Pignato, S., Lipoma, M. (2016) Motor imagery, perspective taking and gender differences: A VVIQ2-based study. Journal of Human Sport and Exercise, 11 228-232. https://doi.org/10.14198/jhse.2016.11.Proc1.13

Di Tore, P.A., Raiola, G., Altavilla, G., Gervilli, M.G., Pignato, S., Lipoma, M. (2016) Visual motor skills and reading fluency: A correlational study. Journal of Human Sport and Exercise, 11(Proc1): S233S238. https://doi.org/10.14198/jhse.2016.11.Proc1.14

Di Tore, P.A., Schiavo, R., D'Isanto, T. (2016) Physical education, motor control and motor learning: Theoretical paradigms and teaching practices from kindergarten to high school, Journal of Physical Education and Sport, 16 (4), 1293-1297. 
Fiorin, I., (2007), La scuola luogo di relazioni e apprendimenti significativi, in A. Canevaro (a cura di), L'integrazione scolastica degli alunni con disabilità, Erickson, Trento, pp. 129-157.

Gaetano, R. (2012) Motor learning and didactics into physical education and sport documents in middle school-first cycle of education in Italy, Journal of Physical Education and Sport, 12 (2), 157-163.

Gaetano, R., Rago, V. (2014) Preliminary study on effects of hiit-high intensity intermittent training in youth soccer players, Journal of Physical Education and Sport, 14 (2), 148-150.

Kelee, R. L. (1984), Micro-Determinism and Concepts of Emergence. Philosophy of Science, 51(1), 4463. https://doi.org/10.1086/289163

Magill, R., A., (2001) Motor learning: concepts and applications (6th ed.), Dubuque, IA: McGraw-Hill.

Pavone, M., (2014), L'inclusione educativa. Indicazioni pedagogiche per la disabilità, Mondadori Education S.p.A., Milano.

Pisapia, F., D'Isanto, T., (2018) Inclusive methods of adaptive training in sprints: a theoretical preliminary study, Journal of Physical Education and Sport, 18, Art 316, pp. 2101-2105.

Rago, V., Pizzuto, F., Raiola, G. (2017) Relationship between intermittent endurance capacity and match performance according to the playing position in sub-19 professional male football players: Preliminary results. Journal of Physical Education and Sport, 17 (2), 688-691.

Raiola, G. (2012) Bodily communication in volleyball between human and experimental sciences, Mediterranean Journal of Social Sciences, 3 (1), 587-597.

Raiola, G. (2013) Body knowledge and motor skills, Knowledge Cultures, 1 (6), 64-72.

Raiola, G. (2014) Motor control and learning skills according to cognitive and ecological dynamic approach in a vision on behaviorism, cognitive, Gestalt and phenomenology theories, Mediterranean Journal of Social Sciences, 5 (15), 504-506. https://doi.org/10.5901/mjss.2014.v5n15p504

Raiola, G. (2014) Teaching method in young female team of volleyball, Journal of Physical Education and Sport, 14 (1), 74-78.

Raiola, G. (2017) Motor learning and teaching method, Journal of Physical Education and Sport, 17, 2239-2243.

Raiola, G., (2012) Didactics of volleyball into the educate program for coaches/trainers/technicians of Italian Federation of Volleyball (FIPAV). Journal of Physical Education and Sport, 12 (1), pp. 25-29.

Raiola, G., D'Elia, F., \& Altavilla, G. (2018). Physical activity and sports sciences between European research council and academic disciplines in Italy. Journal of Human Sport and Exercise, 13(2proc), S283-S295. https://doi.org/10.14198/ihse.2018.13.Proc2.13

Raiola, G., Di Tore, A. (2012) Non-verbal communication and volleyball: A new way to approach the phenomenon, Mediterranean Journal of Social Sciences, 3 (2), 347-356. https://doi.org/10.5901/mjss.2012.v3n2.347

Raiola, G., Di Tore, P.A. (2012) Bodily communication skills and its incidence on female volleyball championship to enhance didactics, Journal of Human Sport and Exercise, 7 (2), 365-375. https://doi.org/10.4100/jhse.2012.72.03

Raiola, G., Di Tore, P.A. (2012) Statistical study on bodily communication skills in volleyball to improve teaching methods, Journal of Human Sport and Exercise, 7 (2), 468-488. https://doi.org/10.4100/jhse.2012.72.12

Raiola, G., Di Tore, P.A. (2017) Motor learning in sports science: Different theoretical frameworks for different teaching methods [Motoričko učenje u sportskoj znanosti: Različiti teorijski okviri za različite metode poučavanja] Sport Science, 10, 50-56.

Schimdt R, Wrisberg D, (2004) Motor Learning and Performance, Human Kinetics USA.

Schmidt, R. A., \& Wrisberg, C. A. (2008) Motor learning and performance: a situation-based learning approach: Human Kinetics Publishers. 
Schmidt, R., A., Wrisberg C.A. (1999) Motor Learning and Performance, Champaign, IL: Human Kinetics (tr. it. 2000, Apprendimento motorio e prestazione. Società Stampa Sportiva, Roma).

Tessaro, F., (2002), Metodologia e didattica dell'insegnamento secondario, ROMA, Armando, pp. 1-268.

\section{(c) (i) $\ominus$}

This work is licensed under a Attribution-NonCommercial-NoDerivatives 4.0 International (CC BY-NC-ND 4.0). 